\title{
Intermédialités
}

Histoire et théorie des arts, des lettres et des techniques

Intermediality

History and Theory of the Arts, Literature and Technologies

\section{On Re-enacting a Hotel Space}

\section{Emanuel Licha}

Numéro 28-29, automne 2016, printemps 2017

refaire

redoing

URI : https://id.erudit.org/iderudit/1041089ar

DOI : https://doi.org/10.7202/1041089ar

Aller au sommaire du numéro

Éditeur(s)

Revue intermédialités (Presses de l’Université de Montréal)

ISSN

1920-3136 (numérique)

Découvrir la revue

Citer cet article

Licha, E. (2016). On Re-enacting a Hotel Space. Intermédialités / Intermediality, (28-29). https://doi.org/10.7202/1041089ar
Résumé de l'article

La découverte d'un hôtel de journalistes dans un camp d'entraînement de l'armée américaine a initié la recherche sur les " hôtels de guerre " qui abritent les reporters couvrant les conflits. Un des résultats de cette recherche est un long-métrage intitulé Hotel Machine, tourné dans les environnements d'après-conflit de cinq hôtels à Sarajevo, Belgrade, Beyrouth, Gaza et Kiev. Les différents moyens utilisés par le film pour « faire parler l'hôtel » sont discutés dans ce texte. 


\title{
On Re-enacting a Hotel Space
}

\author{
EMANUEL LICHA
}

$\mathrm{n}$ the morning of July 2009, I passed the entrance gate of Fort Irwin National

Training Center in the Mojave Desert in California and headed to the office of the Public Affairs Officer (PAO). For months, I had tried to convince him to grant me permission to film in this US Army training facility. My purpose was to document the life in Medina Wasl-a fictitious Iraqi village that the military had set up as training site for soldiers about to be deployed in Iraq or Afghanistan. As I understood later, the reason why I finally found myself in the PAO's office was because he had decided to give me the status of a journalist since he could not find, as he explained, any article in the Rules of Procedure of the camp regulating the presence of artists and filmmakers. The circumstances due to this "misunderstanding" allowed me to experience first-hand the way journalists are treated by the military.

The PAO promptly took me through a crowd of role players dressed as Iraqi villagers (see Fig. I) to a remarkable element of the décor: a hotel built to accommodate media workers stood in the centre of the village (see Fig. 2). A soldierreceptionist wearing a dishdasha met me in the lobby and carried my luggage and equipment to my room. The hotl was rudimentary yet functional. It was the only building in the village furnished and decorated inside: each room had a bed, a table, a (plastic) plant, an armchair, prints on the wall, and an efficient air conditioning system (see Fig. 3). There were only two major inconveniences: there was no running water and no window curtains. With regards to the latter, one was left wondering if the omission was meant to give the occupant an unrestricted access to the stunning view (right on the main square, where all the action took place) or to ensure visual control from the outside on what was happening inside the room. 


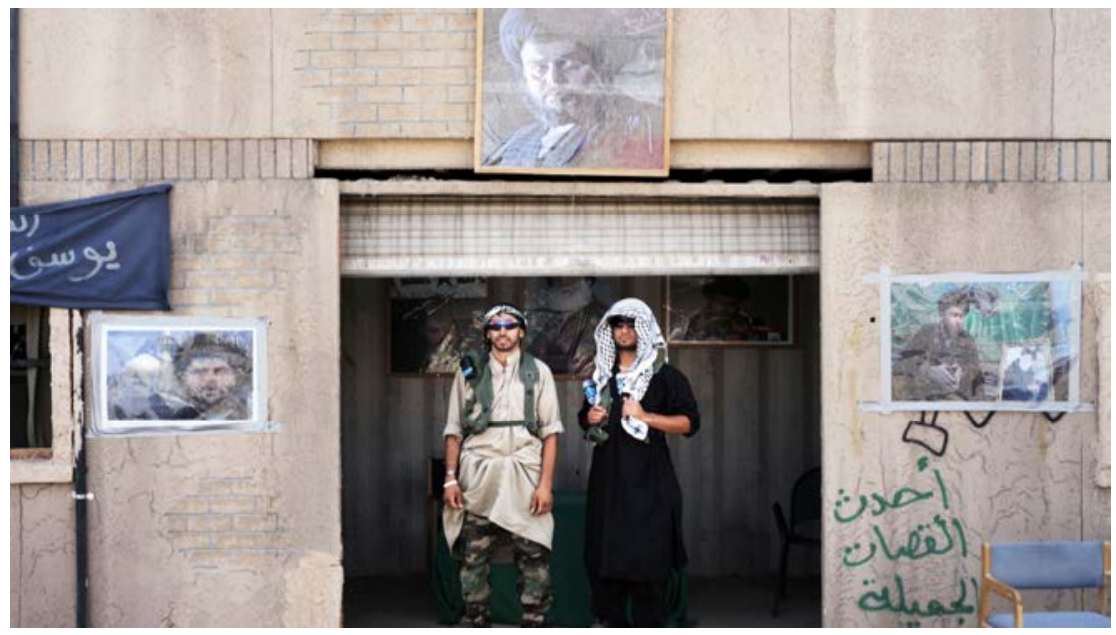

Fig. I. Film still from Mirages, Emanuel Licha, 2oro. Two role players are posing for the camera, in front of a mock Al-Sadr office, in Medina Wasl, Fort Irwin National Training Centre. (c) Emanuel Licha

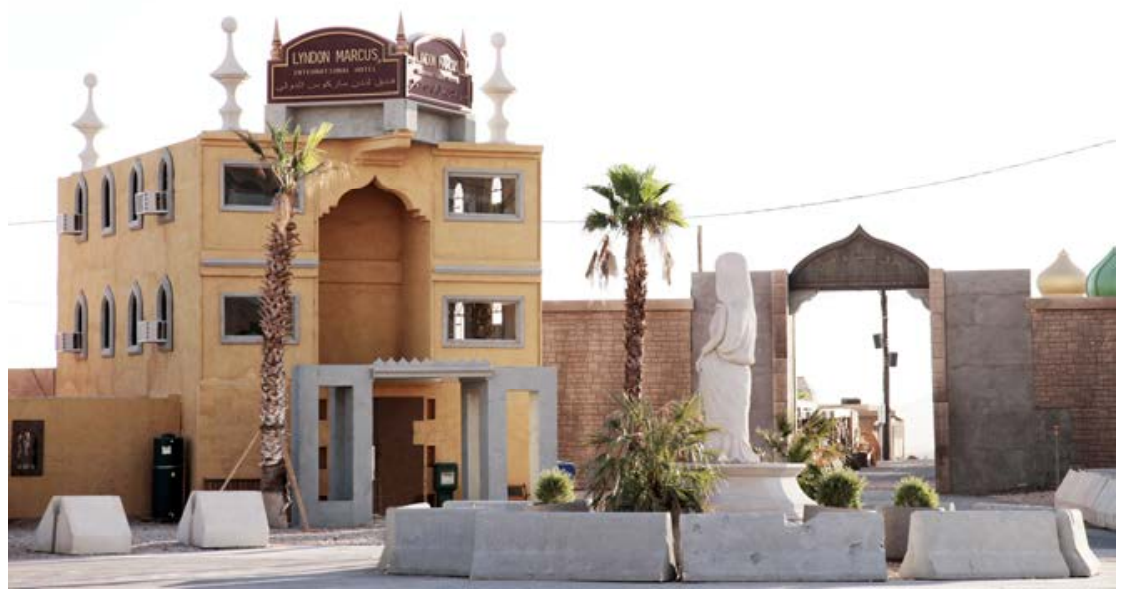

Fig. 2. The hotel where journalists are staying in Medina Wasl at Fort Irwin National Training Centre is, alongside the mosque, the tallest and most richly decorated building in the village. (c) Emanuel Licha 


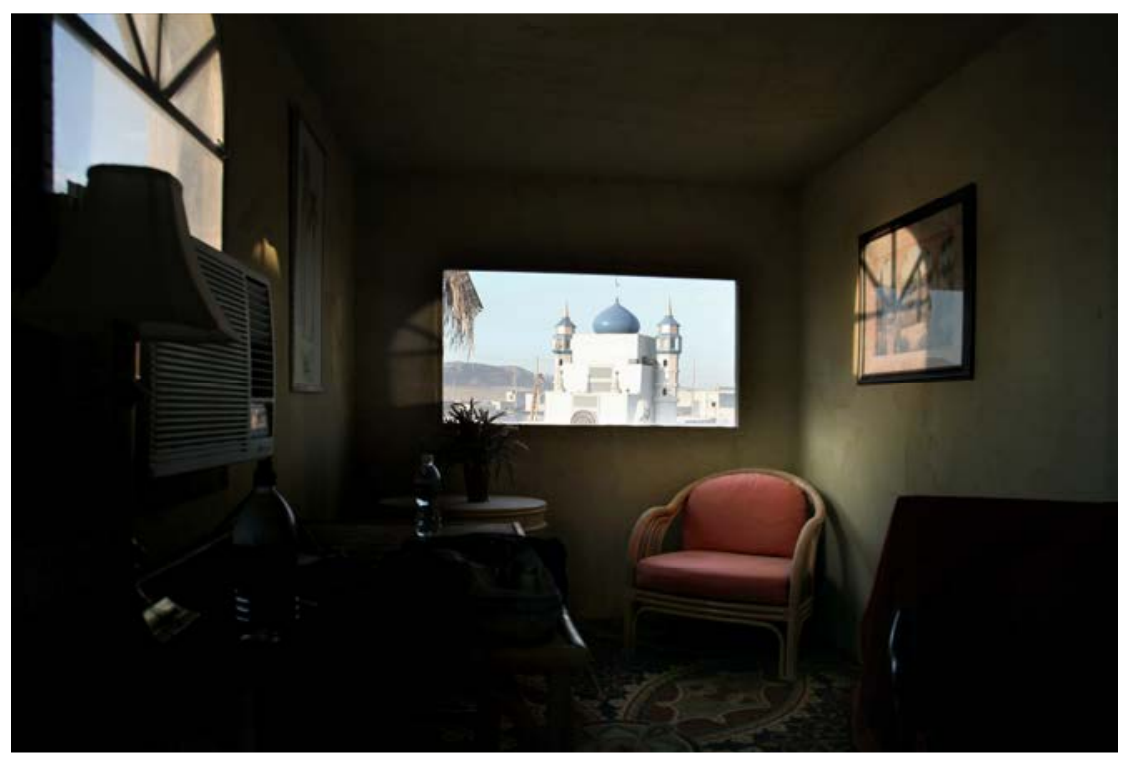

Fig. 3. The hotel room where journalists are staying at Medina Wasl, the mock Iraqi village at Fort Irwin National training Centre. (C) Emanuel Licha

In either case, the absence of curtains drew my attention to the contour of the window. A precise measurement confirmed what had initially been an assumption: the proportions of the window were exactly those of a standard television screen (16:9). What I could see from my hotel room, as the window framed it, were the tip of a rootless palm tree in the foreground and the dome of the mosque in the background. Between the two, all the important and spectacular events of the mock village took place. Within this carefully framed composition, events were effectively ready to be filmed and photographed. All that remained to be done was to turn my camera on.

This very cinematic window and the fact that a reconstitution of a hotel held a prominent place in Medina Wasl-it was both tall and functional, the latter aspect being an exception in this décor, which was mostly made of empty shipping containers-drew my attention to the seemingly awkward presence of a hotel in a training camp. At first sight, it is difficult to imagine that a hotel could have any strategic purpose in the conduct and the unfolding of conflicts, or that the format of its windows could point to the importance of the visual training in warfare. It would indeed be tempting to dismiss the decision of the US military to include such a device in their training facility by looking at it as just an innocuous element in their ongoing preparation for conflict and orchestration of warfare. Instead, to take seriously their claim that hotels and 16:9 windows are effective, or in other words, 
that hotels and the proportions of windows have a role and a function not only in warfare training, but also in conflicts themselves, can help us learn something about conflicts and the way they are seen and represented. Taking a close look at what I called, from that moment on, "war hotels," is a way to enhance our understanding of how conflicts are represented, and thus how they are perceived and in turn potentially influenced by public opinion.

Shortly after this experience in Medina Wasl, I visited a "real-world" war hotel in the city of Antakya in Southern Turkey, at the border with Syria. As their country began to be in turmoil, Syrian refugees started crossing the border with Turkey in the province of Hatay, where the Turkish government, in collaboration with the Red Crescent, had set up refugee camps. Within a few days in June 2oII, media workers from all over the world flocked to Antakya from where they travelled to the refugee camps situated along the Syrian border, which they crossed illegally to report from within Syria. In Antakya, I led the life of a foreign correspondent: I lived in the same hotel, I ate in the same restaurants, went to the same cafés... Like the reporters, I hired a fixer who drove me to the Syrian border where I was able to observe "my colleagues" at work (see Fig. 4). I The photographic and videographic equipment I carried was very similar to that of war photographers, which was enough to identify me as one of them.

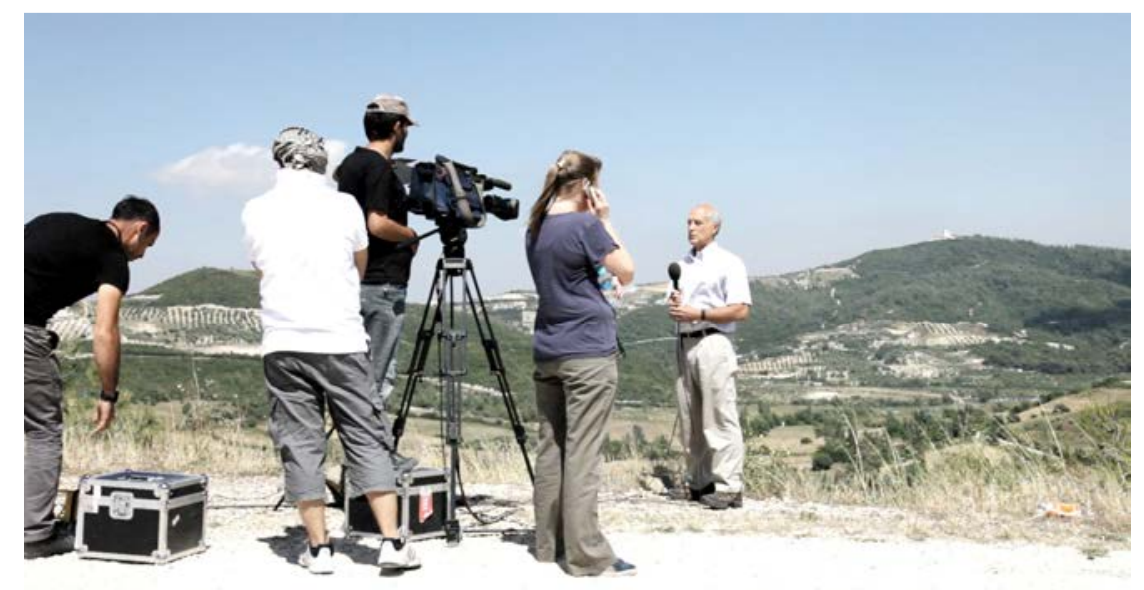

Fig. 4. Still from the film How Do We Know What We Know?, Emanuel Licha, 2011. Observing the work of foreign correspondents in the Turkish province of Hatay at the Syrian border in June 20II. @ Emanuel Licha

\footnotetext{
${ }^{1}$ For a filmic account of that research trip, see the film How do we know what we know?, Emanuel Licha, 20II.
} 
By the third morning, as I was going downstairs to the breakfast room, going through the lobby, and passing by the reception desk, I noticed that entire media crews were checking out. After less than a week of intense media coverage, the city of Antakya and the refugees at the border were not the main news focus anymore. It did not make much sense for me to stay longer, as I had come mainly to observe the journalists' work and how they inhabited their hotel. However, as I had bought the cheapest plane ticket possible, it revealed impossible to change the return date. As a result, I stayed three more days in a city that had been at the centre of the world's attention for a week and that was now a media desert. Not only had I come too late, I also left too late.

Although artists and filmmakers share the same medium with journalists, they do not necessarily work with the same means. Indeed, not only do they not have the same budgets, or any equivalent logistic infrastructure, but their pace and their endeavour also differ substantially. Considering these variations, it is as if an artistic response to a given event, especially in the case of political turmoil, is doomed to be "always too late." Regarding the ever-growing speed with which media operate, "being too late" is commonly understood as a sign of impotence, of being behind, and of being unaware of recent events.

Nevertheless, the three days I spent alone in a media-deserted hotel proved to be determining in the unfolding of the project. It was from this moment on that the hotel staff, restaurant owners, fixers, translators, taxi drivers, who had all spent an intense week collaborating with the media workers, became available to talk to me. I learned more on the work of war correspondents during these three days than I did researching that topic during the few months prior. This is the moment when my decision to "remain late" to direct my film Hotel Machine on war hotels was made. All the subsequent hotels I visited and filmed were in a post-conflict situation in Beirut, Sarajevo, Belgrade, Kiev, and Gaza.

Naturally, questions relating to the temporality of the action of the film were pivotal. Considering the fact that a war hotel only exists when it is in use, the predisposition of the film was that it be shot during a conflict. However, doing so would have put me in the footsteps of the journalist, and although this strategy proved to be productive in Fort Irwin, it would have implied following the flow of actuality and working at a pace that did not seem compatible with a scrutiny of the apparatus of framing and producing knowledge. With the decision to remain within a post-conflict timeframe, the question of whether I would find "loquacious" objects to film posed itself at once. Was there anything lingering in these former war hotels that could be worth filming and that could inform me 
about the way we look at conflicts? This question unleashed a series of others, as so many challenges to the writing phase of the film, and which contributed to shaping the project in their own right. The main challenge in the direction of the film was to render the now somehow banal spaces of the pacified hotels into relevant images. I will discuss three of the strategies that I used to make this "naked" space "talk" on its own, namely: the use of sound, the re-enactments of former protagonists of these spaces, and the integration of archive material.

The sound in the film has various origins: it is at times diegetic (its source is visible on the screen) and non-diegetic at others (the source is not present on screen nor is it implied to be present in the action). The play with both conventions is used to create ambiguity and tension. In Gaza, for example, I noticed that there is almost always the sound of drones in the sky. They are sometimes nowhere to be seen, yet they are constantly heard, even in "peaceful" times. This invisible threat has a constant auditory reminder. In the film, I used this example to create a tension: the sound of a drone was added as a special effect to be heard over very quiet images of the hotel. This creates, on an unconscious level, the impression that something grave is about to happen. It contributes to showing the hotel not only in a historical perspective (this is where it happened) but in a protention as well (it could happen again).

Other sounds from outside, far away, enter the hotel at some specific moments. Those sounds indicate that the outside is under pressure (sirens, disputes between pedestrians, thunder...). They blend with the sounds of the interior or the archives and then gradually disappear. The sounds of everyday objects from the hotel (air conditioning, wireless waves, dripping tap, computer keyboard, dishes manipulated/broken, neon light blinking, phone ringing, et cetera) or caused by a gesture (knocks on the door, fingers patting a table, but also voices, et cetera) are highlighted to write a quasi-musical score of confrontation time.

Another strategy used in the film to "re-enact" the space of the war hotel in a post-conflict time was to convene some of the protagonists of that period. To make the various stories emerge from the hotel and to make that object "speak," the film needed an interpreter and a mediator. Foreign reporters usually attribute this role to fixers. The fixers are their translators and guides, acting as intermediaries to access local sources. The character of the fixer is particularly interesting because he participates in a very concrete way in the framing of the information. The quality of the information greatly relies on his contacts and on the rigour of his translations. 
Following Jacques Rancière's advice that "the real must be fictionalized in order to be thought," ${ }^{2}$ for the purposes of the film, fixers who were active during the war were hired to play their own (former) role. The character of the fixer is seen in the film in various public spaces of the hotel and his presence establishes a link between the hotel as it is today and what it was during the conflict. He seems to be waiting for something, maybe for someone, or for the next conflict to break out and for further contracts with media crews. The first time we see him, he is sitting in the hotel lobby, shuffling through a handful of international journalists' business cards, carefully reading some, dismissing others... It is not clear if he ever left the lobby after the journalists left the country or if he is simply back for a visit. In any case, he seems at ease in this environment, calmly smoking cigarettes or shishas, walking around and talking to the personnel. His function is similar to that of the coryphaeus in the Greek tragedy, who speaks on behalf of the choir that is responsible for telling the background information-everything that could not be represented on stage, such as the great battles-and for summarizing the situations in order to help the public follow the events. The fixer is the only one to look straight into the camera as if addressing the spectators directly. He is saying a text that has been written for him, using his own words after a long preparatory interview concerning his tasks and what happened at the hotel during the conflict. Although there are different fixers for each hotel, they all represent a single character that we recognize by a dress code: he wears a pale blue short-sleeved shirt under a beige "journalist" vest. There is thus only one character of the fixer, with different faces (see Fig. 5-7).

One of the journalists interviewed in the film says: "Knowing the way journalists work, particularly when you're under massive time pressure: you arrive in a country, you have five days, maybe ten days there, you've got to get information as quickly as you can, so of course, the people who run the bar in the hotel, or the women who drop in to clean the bedroom are all potential sources of information." For Hotel Machine as well they became important sources of information, especially since they are the unique direct witnesses we could meet inside the hotel after everyone else had left it. The employees who tell a story of the hotel in wartime are filmed while working, in conversation with colleagues. They never look directly into the camera. One of the opening sequences shows two hotel waiters in a semi-dark conference room filled with chairs (see Fig. 8). One asks: "Do

\footnotetext{
2 Jacques Rancière, Le Partage Du Sensible, Paris, La Fabrique, 2000, p. 6I.
} 

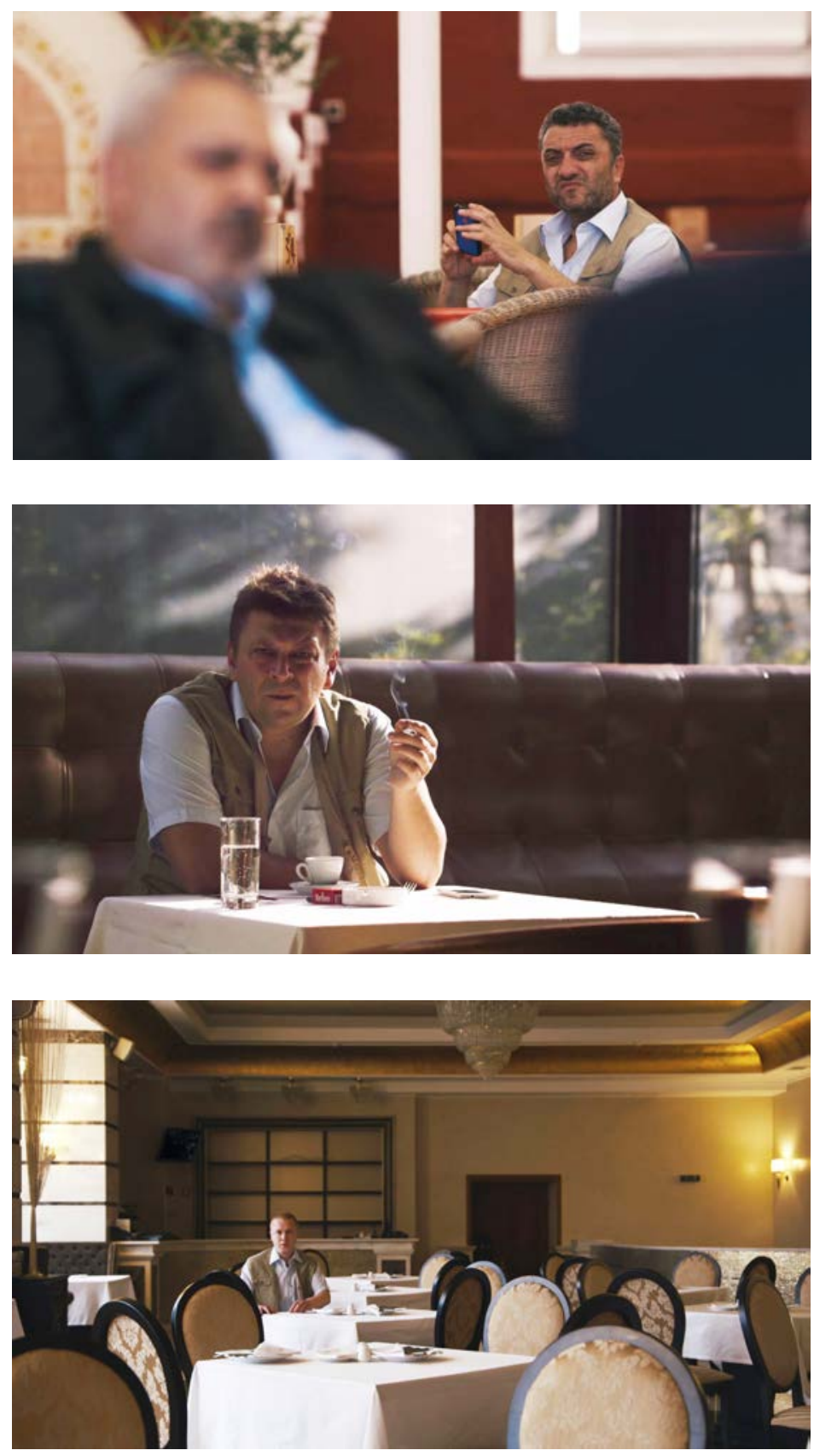

Fig. 5-7. Stills from the film Hotel Machine, Emanuel Licha, 2016. The fixer has different faces, but he is one single character. (C) Emanuel Licha 
you remember who was here?" His colleague answers: "Fifty war reporters during three years." We understand that this scene takes place in what used to be the dining room of the hotel during the conflict. In a mnemonic action, they start reordering the chairs, placing them as they were when journalists had dinner there. They try to remember where each of the journalists sat and they place the chairs accordingly: "Can you remember who was sitting where?" one of them asks. "Christiane Amanpour was sitting here," and further away, "a French crew had a table of eight." This scene is emblematic of what I tried to achieve with this filmic dispositif: to have the hotel, including its objects and its personnel, "speak" about what it "did" during the conflict.

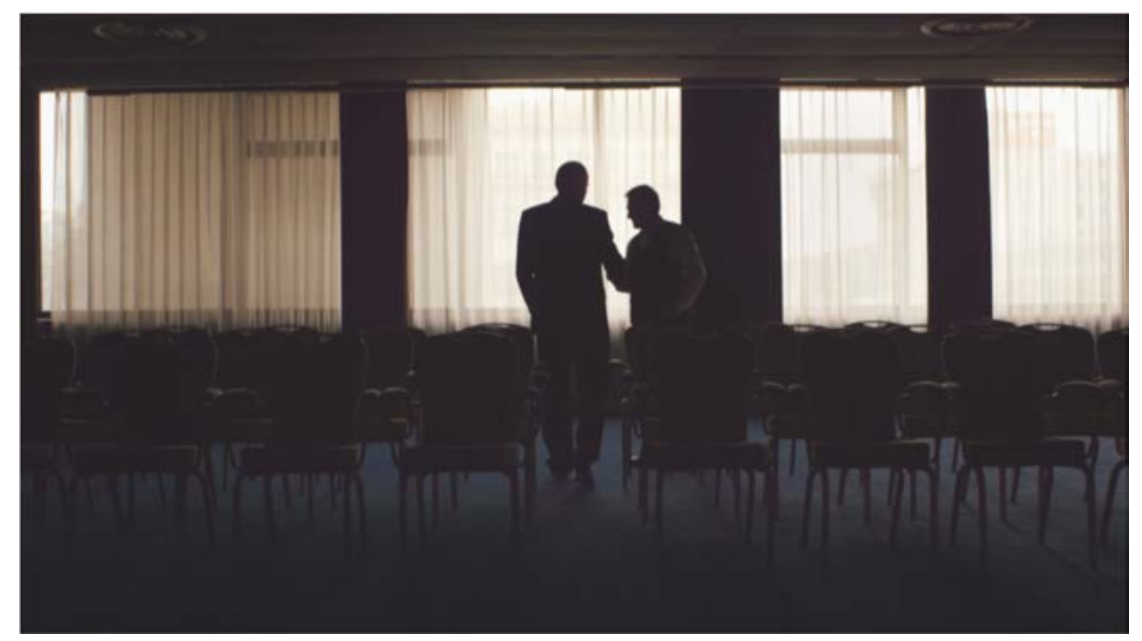

Fig. 8. Excerpt from Hotel Machine (http://retro.erudit.org/media/im/Io4lo8gar /ro4ro89arvooi.mp4), Emanuel Licha, 2016. Two waiters are arranging the chairs to reconstitute the former dining room.

This sequence highlights the efficiency of the mnemonic process that consists in associating testimony to a meaningful space. It is a dispositif that I had already explored in my film Green, Green Grass of Home (Emanuel Licha and Maja Bajević, 2002) in which a former inhabitant of Sarajevo is seen in an empty field describing the plan of the apartment she lost during the war (see Fig. 7). She tries to remember the layout of the place in details, walking in the field as if she were inside the apartment: she goes "from one room to the other," describing the content of each and telling anecdotes. This filmic process, inspired by methods used in the discipline of psychology for instance, reminds us that history remains vivid in the present as it translates into various signs, emitted by speech, body language, actions, and traces of various sorts. 


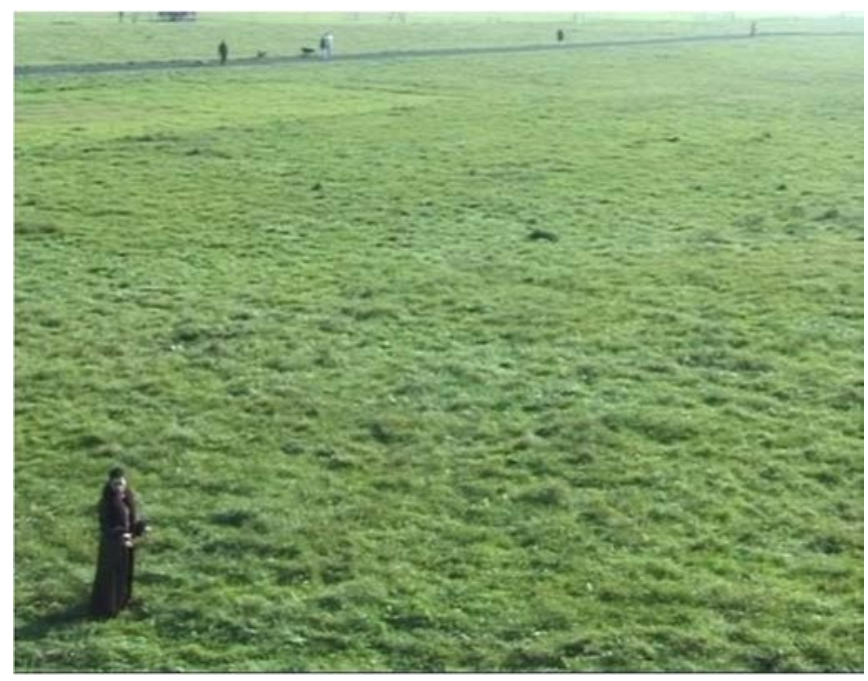

Fig. 9. excerpt from Green, Green Grass of Home (http://retro.erudit.org/media/im /I04I089ar/I04I089arvo02.m4v), Emanuel Licha, in collaboration with Maja Bajević, 2002. (c) Emanuel Licha

A film is a good format to unveil these traces and to give them a new resonance by juxtaposing them through montage. In the case of a project looking at the roles war hotels played over a period of more than twenty years, a film allows the shuffling of various temporalities in order to question what is left of these past roles in the present. The spatial and temporal conflations in Hotel Machine are the most manifest with the use of archive material. Monitors or screens available in the hotel (the television monitor in the rooms, the lobby, the lounges or the bar, the screens in the conference room, and other available computers), as well as radio sets, are used to broadcast archive material recorded in or from a hotel during a conflict. The evocation of the past through archive material enables the spectator to weigh the relevance of these spaces in the present.

These hotels were hastily repaired after the conflict, and with the rare exception of the Ukraine Hotel in Kiev where I filmed only two months after the events of February 2014 and where there were still bullet holes in some windows, they bear no (visible) scars from the combats. The dispositif of the film unveils these scars. For example, in the opening sequence we see a housekeeping employee calmly dusting the reception desk. It is only much later, towards the end of the film, that we see him once again, this time in a news broadcast on a television monitor in a room: he is shown carrying the body of a wounded boy, after the July 16,2014 attack on a beach in Gaza (see Fig. IO-II). 
Another example is taken from the moment when the lobby of the Ukraine Hotel was transformed into a makeshift hospital: archive footage showing the wounded bodies in the lobby is broadcast on a television monitor placed in the exact same space (see Fig. I2). We know it is the same space because we recognize the armchairs, which appear both in the main image and in the broadcast. In the archive, we also see stairs where journalists are standing, photographing, and filming the chaotic scene below (see Fig. 13, image detail). In the following shot, we see a housekeeper quietly wiping the same stairs today. A voiceover-hers, which was not recorded at the same time she was filmed, thus constituting a third temporality-is heard telling the horrific story of that day (see Fig. I4). The contrast between a seemingly un-agitated décor and the violence of its past (or in the case of Gaza, for instance, its future, as the attack took place three months after I filmed in that hotel) is shown repeatedly throughout the film, by juxtaposing images of the pacified space with other disquiet images or sounds from archive material. To explain how these various temporalities blend in, Elizabeth Grosz describes, after Bergson, a "persistence of the past in the present":

The past, in other words, is not only the condition of the present but also the condition of every possible future that may arise from or be made out of the present. Which is another way of saying that the past is infinitely reflective: it is revived, returned to relevance, rewritten (that is, actualized) in potentially infinite (future) forms. [...] It is not so much revived by the present as it seeks activity, reactivation in whatever form the present may enable. The active force is not simply the present seeking out past resemblances and relevancies, precedents; it is also the past seeking to extend itself and its potential into the present, waiting for those present events that provide it with revivification. ${ }^{3}$

Hotel Machine enables the possibility not only for a ubiquitous stance, but also to perform jump cuts in time, as these operations are part of its very grammar. This temporal conflation is not meant to obfuscate, on the contrary. It is rather meant to highlight how former practices, as well as memory, continue to influence and to build the present. Past is embedded in the present, which makes it possible to represent the past, and to some extent the future as well. Film matters in this regard, as it is able to entangle different temporalities in the most consistent way.

3 Elizabeth Grosz, The Nick of Time: Politics, Evolution, and the Untimely, Durham, North Carolina, Duke University Press, 2004, p. 254. 


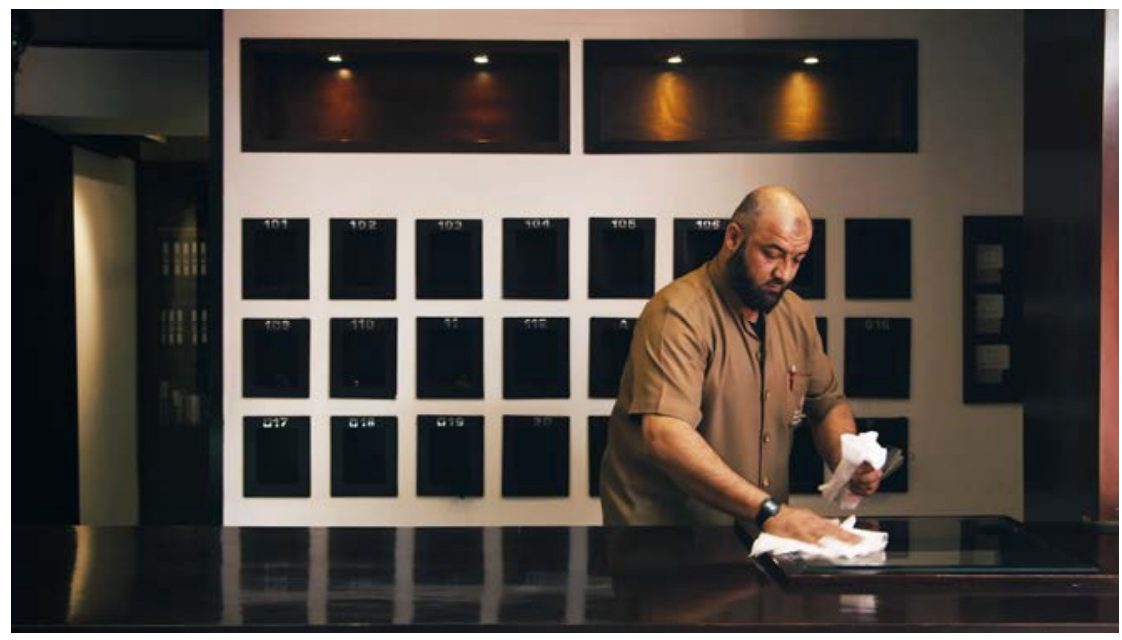

Fig. Io. Still from the film Hotel Machine, Emanuel Licha, 2016. An employee of the Al-Deira Hotel in Gaza, seen at work and, in the next image, in a news report. Film stills from Hotel Machine. (c) Emanuel Licha

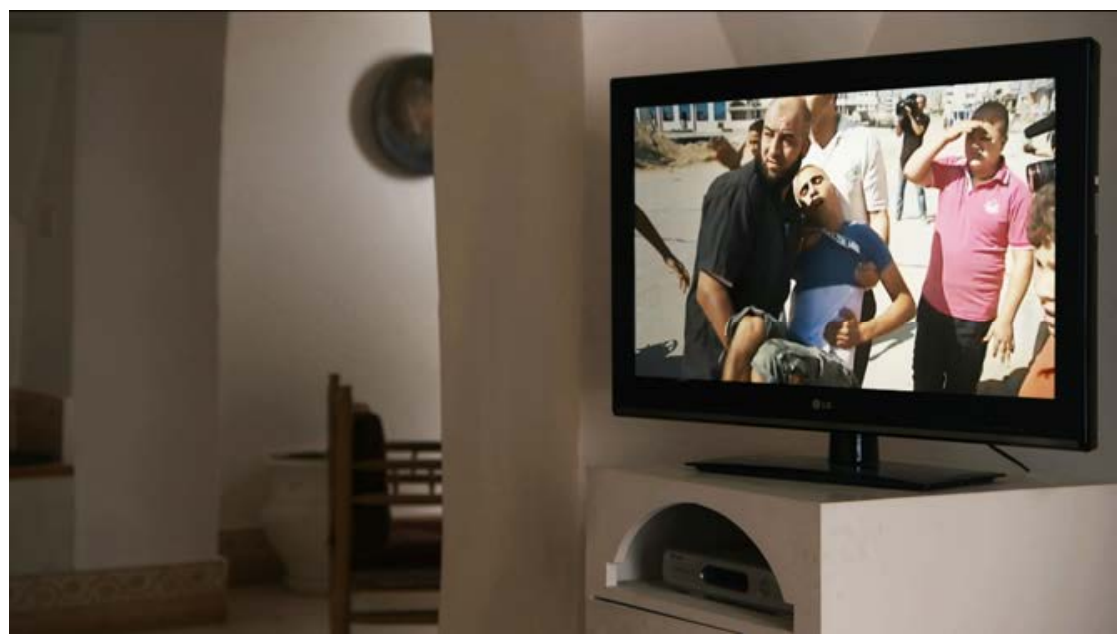

Fig. II. Still from the film Hotel Machine, Emanuel Licha, 20I6. An employee of the Al-Deira Hotel in Gaza, seen at work in the previous image, is featured on a news report. (c) Emanuel Licha 


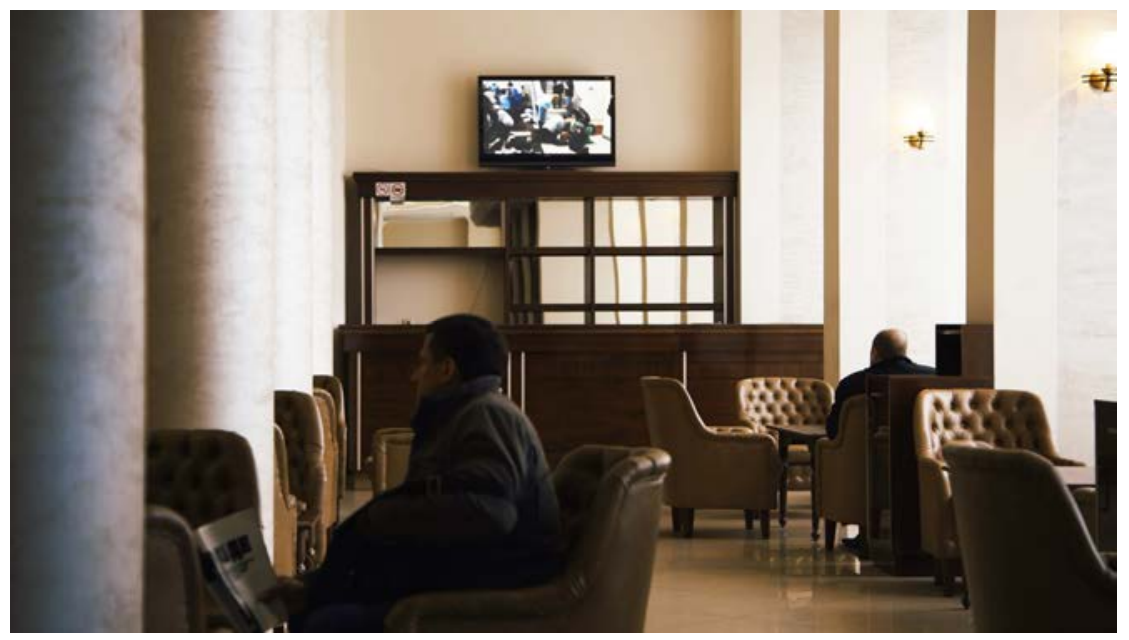

Fig. I2. Still from the film Hotel Machine, Emanuel Licha, 2016. The lobby of the Hotel Ukraine with a broadcast of the scenes that happened in the exact same place two months earlier (detail in the next image). ( $)$ Emanuel Licha

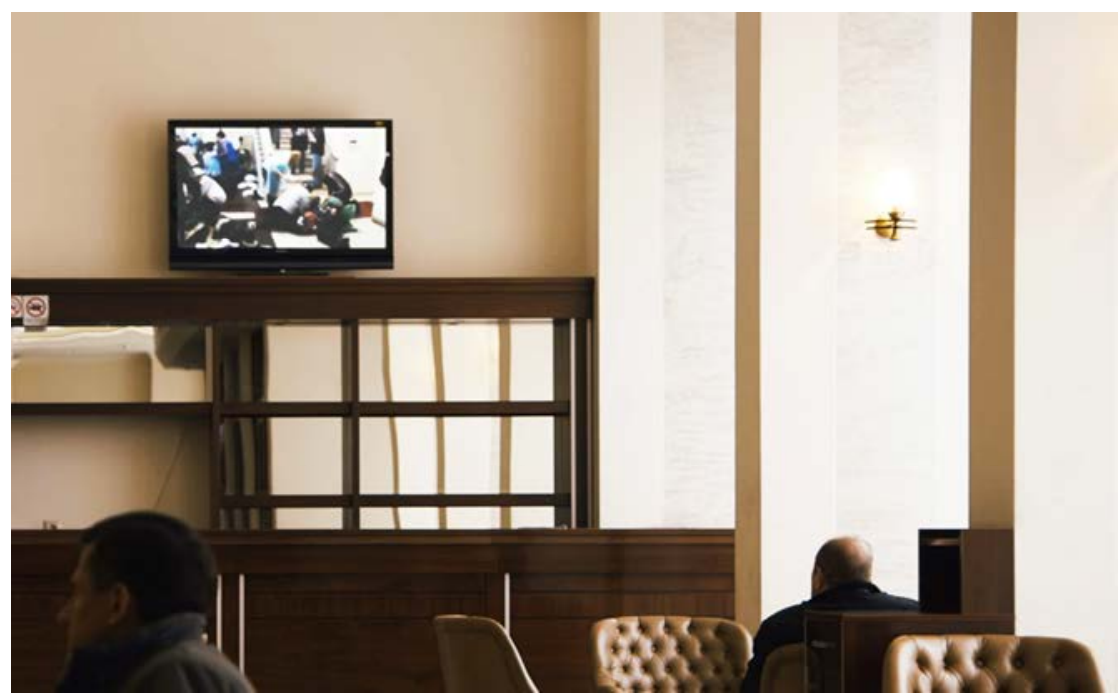

Fig. 13. Still from the film Hotel Machine, Emanuel Licha, 2016. The lobby of the Hotel Ukraine with a broadcast of the scenes that happened in the exact same place two months earlier (detail). (C) Emanuel Licha 


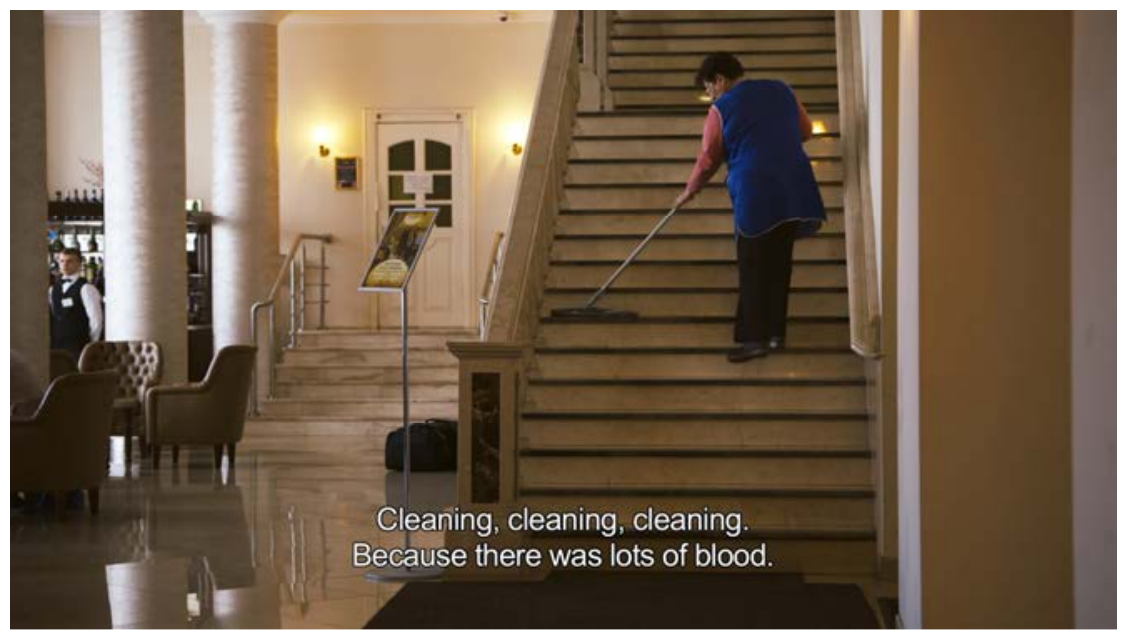

Fig. I4. Still from the film Hotel Machine, Emanuel Licha, 20I6. An employee of the hotel recalls the day of the massacre on Maidan. ( Emanuel Licha 


\title{
On Re-enacting a Hotel Space
}

\author{
EMANUEL LICHA
}

\section{RÉSUMÉ}

La découverte d'un hôtel de journalistes dans un camp d'entraînement de l'armée américaine a initié la recherche sur les « hôtels de guerre » qui abritent les reporters couvrant les conflits. Un des résultats de cette recherche est un long-métrage intitulé Hotel Machine, tourné dans les environnements d'après-conflit de cinq hôtels à Sarajevo, Belgrade, Beyrouth, Gaza et Kiev. Les différents moyens utilisés par le film pour « faire parler l'hôtel » sont discutés dans ce texte.

\section{ABSTRACT}

The presence of a hotel for journalists in a US Army training facility prompted the research on "war hotels" used by media workers when they cover a conflict. One of the results of this research is a feature-length film titled Hotel Machine, which was shot in the post-conflict environment of five hotels situated in Sarajevo, Belgrade, Beirut, Gaza, and Kiev. The various techniques used in the film to "make the hotel speak" are discussed in this essay.

\section{NOTE BIOGRAPHIQUE}

Trained initially in urban geography and then visual arts, Emanuel Licha is an artist and filmmaker. His work in film, video installation, and photography focuses on the role of spatial objects in the representation and the understanding of geopolitical events, leading to a reading of the features of the urban landscape as social, historical, and political signs. His recent projects investigate the means by which traumatic and violent events are being looked at. Emanuel Licha is also an Assistant Professor in the Department of Art History and Film Studies at the Université de Montréal. He holds a PhD in Visual Cultures from the Centre for Research Architecture, Goldsmiths, University of London. 